\title{
Factors Associated with Iron Deficiency in Elementary School Children
}

\author{
Rostika Flora ${ }^{1 *(\mathbb{D})}$, Mohammad Zulkarnain $^{2}$ D, Nur Alam Fajar ${ }^{1}$, Annisah Biancika Jasmine ${ }^{1}$, Indah Yuliana ${ }^{3}$, \\ Risnawati Tanjung ${ }^{4}$, Sulaiman Sulaiman ${ }^{5}$, Sumitro Adi Putra ${ }^{5}$, Sri Martini ${ }^{5}$, , Aguscik Aguscik ${ }^{5}$ (i) \\ ${ }^{1}$ Master of Public Health Science Study Program, Faculty of Public Health, Sriwijaya University, Palembang, Indonesia; ${ }^{2}$ Public \\ Health Science Study Program, Faculty of Medicine, Sriwijaya University, Palembang, Indonesia; ${ }^{3}$ Nutrition Study Program, \\ Faculty of Public Health, Sriwijaya University, Palembang, Indonesia; ${ }^{4}$ Environmental Health Study Program, Health Polytechnic \\ of the Ministry of Health, Medan, Indonesia; ${ }^{5}$ Nursing Study Program, Health Polytechnic of the Ministry of Health, Palembang, \\ Indonesia
}

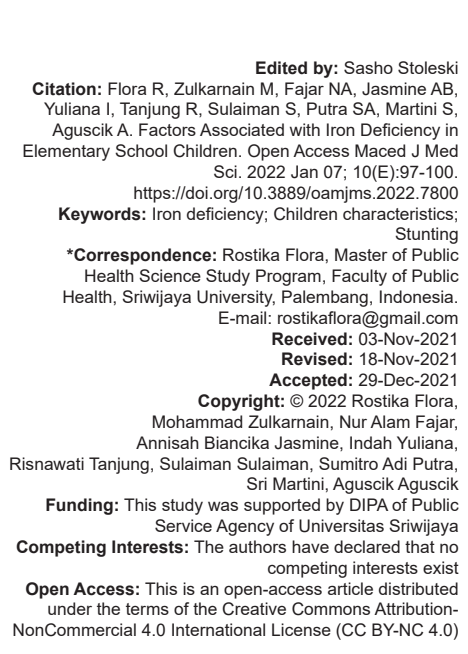

\section{Background}

Iron deficiency is a public health problem that often occurs in developing countries. It is estimated that $2 / 3$ of children and adolescents have iron deficiency, and $25 \%$ of preschool children have iron deficiency anemia. The WHO data (2011) state that two billion people in the world suffer from iron deficiency anemia. Approximately $50 \%$ of cases of anemia are caused by iron deficiency. In Africa, the incidence of iron deficiency anemia in school children reaches $64.3-71 \%$ [1], [2], while in Indonesia, based on the results of Basic Health Research in 2013; it is $29 \%$ [3].

Iron deficiency anemia occurs when a decrease in hemoglobin levels accompanies iron deficiency. Iron is obtained from food intake and absorbed in the upper gastrointestinal tract. Low iron intake results in limited absorption of iron that the digestive system can absorb. If there is an imbalance between intake and needs, there will be iron deficiency. Anemia does not occur at this stage, but serum ferritin levels and serum transferrin saturation levels decrease. If this condition is not overcome, it will continue to the next stage, namely, iron deficiency anemia [4]. According to the Miniero et al. (2018), 30\% of cases of iron deficiency that are not treated will develop into iron deficiency anemia [5].

Iron deficiency anemia results in not optimal cognitive development. It is difficult to concentrate, so that children's learning achievement will decrease. The brain requires a lot of iron because the oxidation metabolism that occurs in the brain is higher than in other organs. Therefore, iron must be transferred to brain cells with good regulation because iron availability is very influential on brain function [6]. Children with 
iron deficiency tend to have low cognitive function and academic achievement [7].

The prevalence of anemia in school children in Indonesia is still relatively high. In addition to behavior and diets that are low in iron sources, the problem of poverty, which generally occurs in rural and or mountainous areas, is a contributing factor to the high rate of iron deficiency anemia [8]. The results of Riskesdas 2013 show iron deficiency anemia in schoolage children in rural areas by $31 \%$ [3].

The results of the research by Flora et al. (2019) regarding the distribution of stages of iron deficiency anemia in elementary school children in Tuah Negeri District found that $15.4 \%$ of children had anemia without iron deficiency, $33 \%$ of children had iron deficiency, $37.4 \%$ of children had iron deficiency anemia, and only $14.3 \%$ of children did not have iron deficiency or iron deficiency anemia. Many factors cause iron deficiency and iron deficiency anemia [9]. This study aims to analyze the dominant factors causing iron deficiency in elementary school children in Tuah Negeri District.

\section{Methods}

The design of this study was cross-sectional, with a sample of elementary school children aged 9-12 years in Tuah Negeri District. Previously, blood was taken for measurement of serum iron. Measurement of serum iron levels was carried out by the spectrophotometric method. Based on the results of iron measurements, children are grouped into two groups, namely, iron deficiency and normal. Each group consists of 85 children, and the total sample is 170 children.

Furthermore, data on child characteristics (age, gender, and nutritional status) and parental characteristics (education, occupation, and economic status) were collected. Measurement of nutritional status based on TB/U, Z-score was calculated using Anthro 1.02 software. The measurement results were categorized into stunting and normal. Data were analyzed univariate, bivariate, and multivariate using Statistical Package for the Social Sciences version 22. This study has received ethical approval from the Ethics Commission of the Faculty of Public Health, Sriwijaya University. 170/UN9.1.10/KKE/2021.

\section{Results}

Data on the characteristics of children and parents (Table 1) show that $60 \%$ of children aged
Table 1. Frequency distribution of elementary school children in Tuah Negeri district

\begin{tabular}{lll}
\hline Frequency distribution & $\mathrm{n}$ & $\%$ \\
\hline Age & & \\
$\quad 9-10$ year & 68 & 40 \\
$\quad>10-12$ year & 102 & 60 \\
Gender & & \\
$\quad$ Male & 78 & 45.9 \\
$\quad$ Female & 92 & 54.1 \\
Mother's Education & & \\
$\quad$ Low & 115 & 67.6 \\
$\quad$ High & 55 & 32.4 \\
Mother's Occupation & 143 & 84.1 \\
$\quad$ Employed & 27 & 15.9 \\
$\quad$ Unemployed & & \\
Father's Education & 126 & 74.1 \\
$\quad$ Low & 44 & 25.9 \\
$\quad$ High & & \\
Father's Occupation & 94 & 55.3 \\
$\quad$ Farmer & 76 & 44.7 \\
$\quad$ Not Farmer & & \\
Economic Status & 93 & 54.7 \\
$\quad$ Low & 77 & 45.3 \\
$\quad$ High & & 23.5 \\
Nutritional Status & 40 & 76.5 \\
$\quad$ Stunting & 130 & \\
$\quad$ Normal & &
\end{tabular}

$>10-12$ years, $54.1 \%$ are female, and $23.5 \%$ of children are stunted. Data on the characteristics of parents obtained $67.6 \%$ of mothers and $74.1 \%$ of fathers with low education; $84.1 \%$ of mothers and $55.3 \%$ of fathers work as farmers, and $54.7 \%$ have low economic status. The results of bivariate analysis (Table 2) regarding the characteristics of children and parents with the incidence of iron deficiency, it was found that there was no significant relationship between age $(p=0.754)$, gender $(p=0.124)$, mother's education $(p=0.140)$, mother's occupation ( $p=0.834)$, father's education $(p=0.726)$, and father's occupation $(p=0.537)$ with the incidence of iron deficiency. Only two variables, namely, economic status $(p=0.003)$ and nutritional status $(p<0.001)$, were significantly related to the incidence of iron deficiency in elementary school children.

Table 2: Relationship between child characteristics and serum iron status

\begin{tabular}{|c|c|c|c|c|c|}
\hline \multirow[t]{3}{*}{ Children characteristics } & \multicolumn{4}{|c|}{ Serum iron status } & \multirow[t]{3}{*}{$\mathrm{p}$} \\
\hline & \multicolumn{2}{|c|}{ Deficiency } & \multicolumn{2}{|c|}{ Normal } & \\
\hline & $\mathrm{n}$ & $\%$ & $\mathrm{n}$ & $\%$ & \\
\hline \multicolumn{6}{|l|}{ Age } \\
\hline $9-10$ year & 33 & 48.5 & 35 & 51.5 & \multirow[t]{2}{*}{0.754} \\
\hline$>10-12$ year & 52 & 51.0 & 50 & 49.0 & \\
\hline \multicolumn{6}{|l|}{ Gender } \\
\hline Male & 34 & 43.6 & 44 & 56.4 & \multirow[t]{2}{*}{0.124} \\
\hline Female & 51 & 55.4 & 41 & 44.6 & \\
\hline \multicolumn{6}{|l|}{ Mother's Education } \\
\hline Low & 62 & 53.9 & 53 & 46.1 & \multirow[t]{2}{*}{0.140} \\
\hline High & 23 & 41.8 & 32 & 58.2 & \\
\hline \multicolumn{6}{|l|}{ Mother's Occupation } \\
\hline Employed & 13 & 48.1 & 14 & 51.9 & \multirow[t]{2}{*}{0.834} \\
\hline Unemployed & 72 & 50.3 & 71 & 49.7 & \\
\hline \multicolumn{6}{|l|}{ Father's Education } \\
\hline Low & 64 & 50.8 & 62 & 49.2 & \multirow[t]{2}{*}{0.726} \\
\hline High & 21 & 47.7 & 23 & 52.3 & \\
\hline \multicolumn{6}{|l|}{ Father's Occupation } \\
\hline Farmer & 49 & 52.1 & 45 & 47.9 & \multirow[t]{2}{*}{0.537} \\
\hline Not Farmer & 36 & 47.4 & 40 & 52.6 & \\
\hline \multicolumn{6}{|l|}{ Economic Status } \\
\hline Low & 56 & 60.2 & 37 & 39.8 & \multirow[t]{2}{*}{0.003} \\
\hline High & 29 & 37.7 & 48 & 62.3 & \\
\hline \multicolumn{6}{|l|}{ Nutritional Status } \\
\hline Stunting & 33 & 82.5 & 7 & 17.5 & \multirow[t]{2}{*}{0.000} \\
\hline Normal & 52 & 40.0 & 78 & 60.0 & \\
\hline
\end{tabular}

Based on the results of multivariate analysis (Table 3), it was found that economic status $(p=0.011)$ and nutritional status ( $p<0.001$ ) were related to serum iron status. Children with low economic status 
are 2.361 times at risk for iron deficiency and stunting children are 6.785 times at risk for iron deficiency. Stunting is the most dominant factor associated with iron deficiency in children.

Table 3: Multivariate analysis results

\begin{tabular}{lllll}
\hline Variable & $\mathrm{p}$ & OR & \multicolumn{2}{c}{$95 \% \mathrm{Cl}$ for Exp (B) } \\
\cline { 5 - 5 } & & & Lower & Upper \\
\hline Economic Status & 0.011 & 2.361 & 1.218 & 4.578 \\
Stunting & 0.000 & 6.785 & 2.754 & 16.713 \\
\hline
\end{tabular}

\section{Discussion}

This study indicates that stunting is the most dominant factor associated with iron deficiency in elementary school children in Tuah Negeri District. Low economic status affects the adequacy of iron intake in children. Insufficient food intake will lead to hidden hunger or nutritional problems that are not visible due to a lack of micronutrients, such as iron. Children more often consume foods high in carbohydrates, but low in food ingredients such as animal side dishes, vegetables, and fruit [10]. In general, iron in meat, chicken, and fish has high biological availability, iron in cereals and beans has biological availability. Most vegetables' moderate in iron, especially those containing high oxalic acid, such as spinach, have low biological availability. Therefore, the daily food combination is crucial and must consist of iron sources derived from animals and plants [11].

Iron is one of the essential micronutrients that affect growth. One of them is as a component of the ribonucleotide reductase enzyme, which participates in DNA synthesis, which works indirectly on tissue growth that can affect growth [12]. In addition, iron is a cytochrome component that can participate in the production of adenosine triphosphate and protein synthesis, affecting tissue growth [2]. Iron deficiency will impact the body's immune ability, so infectious diseases can easily enter the body. Iron deficiency anemia and prolonged infectious diseases will impact the linear growth of children or stunting [13]. The results of this study are in line with the results of research conducted by Ayoya et al. which stated that there is a relationship between the incidence of stunting and the incidence of iron deficiency anemia. Stunting toddlers have a 2 times greater risk of developing iron deficiency anemia than non-stunted toddlers [14]. The results of Flora et al.'s study also showed a decrease in serum iron levels in children who were stunted compared to children who were not stunted $(34.33 \pm 12,73 \mu \mathrm{g} / \mathrm{dL}$ vs. $42.79 \pm 19.45 \mu \mathrm{g} / \mathrm{dL})$, There was a significant difference $(p=0.011)$ in the mean serum iron level between stunted and non-stunted children [15]. Damayanti et al.'s research also stated that there was a significant relationship between the level of iron adequacy and stunting [13].

The prevalence of stunting in school-age children (6-12 years) in Indonesia is 30.7\% [3]. The high prevalence of stunting shows that nutritional problems in Indonesia are chronic problems related to poverty, low education, inadequate services, and environmental health. Many interrelated factors can directly influence nutritional problems by infectious diseases and lack of nutritional intake in quality and quantity, while indirectly influenced by the reach and quality of health services, inadequate child care patterns, environmental sanitation, and low food security at the household level [16]. The data on the characteristics of parents in this study showed that $67.6 \%$ of mothers and $74.1 \%$ of fathers had low education; $84.1 \%$ of mothers and $55.3 \%$ of fathers work as farmers, and $54.7 \%$ have low economic status. This condition affects the availability of food at the household level, which impacts the incidence of stunting in the Tuah Negeri District.

Stunting reflects poor linear growth. This condition has accumulated since the pre- and post-natal period caused by poor nutrition and health. Stunting at an early age will negatively affect intelligence, psychomotor development, fine motor skills, and neurosensory integration [17]. School children are generally in a period of very rapid and active growth; a well-nourished, balanced, and diverse diet will ensure adequate nutrition [18].

This study describes the condition of iron status in children from Fe serum level examination; however, this study did not measure iron intake. Measurement of iron intake can describe the amount and type of iron consumed by children, thus the amount of iron consumed and iron serum in the body could have been compared.

\section{Conclusion}

Stunting is the dominant factor associated with iron deficiency in elementary school children in Tuah Negeri District. Stunting children are at risk of 6.785 times $(p=0.000)$ greater iron deficiency than children who are not stunted.

\section{Acknowledgment}

This research of this article was funded by DIPA of Public Service Agency of Universitas Sriwijaya. SP DIPA-023.17.2.677515/2021, on November 23, 2020. In accordance with the Rector's Decree Number: 0010/ UN9/SK.LP2M.PT/2021, on April 28, 2021. The authors gratefully acknowledge those who had contributed their generous support in completing this work. 


\section{References}

1. Van der Merwe LF, Eussen SR. Iron status of young children in Europe. Am J Clin Nutr. 2017;106(Suppl 6):1663S-71S. https:// doi.org/10.3945/ajcn.117.156018

\section{PMid:29070549}

2. Andrews NC, Ullrich CK, Fleming MD. Disorders of iron metabolism and sideroblastic anemia. In: Orkin SH, Nathan DG, Ginsburg D, Look AT, Fisher DE, Lux SE, editors. Nathan and Oski' Hematology of Infancy and Childhood. Canada: Sauders Elsevier; 2009. p. 521-70.

3. Kementerian Kesehatan Republik Indonesia. Riset Kesehatan Dasar (RISKESDAS) tahun 2013. Jakarta: Badan Penelitian dan Pengembangan Kesehatan Kementerian Kesehatan Republik Indonesia; 2013.

4. Bakta IM. Hematologi Klinik Ringkas. Jakarta: EGC; 2007.

5. Miniero, R, Talarico V, Galati MC, Giancotti L, Saracco P, Raiola G. Iron Deficiency and Iron Deficiency Anemia in Children. London: IntechOpen; 201810.

6. Connor JR, Benkovic SA. Iron regulation in the brain: Histochemical, biochemical, and molecular consider-ation. Ann Neurol. 1992;32(Suppl):S51-61. https://doi.org/10.1002/ ana.410320710

PMid:1510381

7. Nokes C, Bosch C, Bundy DA. The Effects of Iron Deficiency Anemia on Mental and Motor Performance, Educational Achievement and Behavior in Children: An Annotated Bibliography. Available from: http://www.aii.ilsi.org/file/ACF179. pdf [Last accessed on 2021 Oct 10].

8. Bekele G, Wondimagegn A, Yaregal A, Lealem G. Anemia and associated factors among school-age children in filtu town, Somali Region, Southeast Ethiopia. BMC Hematol. 2014;14(7):9511-28. https://doi.org/10.1186/2052-1839-14-13 PMid:25170422

9. Flora R, Zulkarnan M, Faja NA, Faisa AF, Yuliana I, Nurlaili I, et al. Profil Tahapan Anemia Defisiensi Besi Pada Anak Sekolah
Dasardi Daerah Pedesaan: Studi Cross Sectional di Kecamatan Tuah Negeri Kabupaten Musi Rawas; 2020. Available from: http://semnas.fkm.unsri.ac.id/index.php/prosiding [Last accessed on 2021 Sep 27].

10. Sumedi E, Sandjaja S. Asupan zat besi, Vitamin A dan zink anak indonesia umur 6-23 bulan. Penelitian Gizi Makanan. 2015;38(2):167-75

11. Ahmed F, Khan MR, Jackson AA. Concomitant supplemental Vitamin A enhances the response to weekly supplemental iron and folic acid in anemic teenagers in Urban Bangladesh. Am J Clin Nutr. 2001;74(1):108-15. https://doi.org/10.1093/ ajcn/74.1.108 PMid: 11451725

12. Harmatz P, Butensky E, Lubin B. Nutrion in Pediatrics Basic Science and Clinical Application. London. Churchill Livingstone; 2003.

13. Damayanti RA, Muniroh L, Farapti F. Perbedaan Tingkat Kecukupan Zat Gizi dan Riwayat Pemberian AS. Vol. 11. Media Gizi Indonesia; 2016. http://dx.doi.org/10.20473/mgi. v11i1.61-69

14. Ayoya MA, Ngnie-Teta I, Séraphin MN, Mamadoultaibou A, Boldon E, Saint-Fleur JE, et al. Prevalence and risk factors of anemia among children 6-59 months old in haiti. Anemia 2013;2013:502968.

15. Flora R, Zulkarnain M, Fajar NA, Faisa AF, Nurlaily N, Ikhsan I, et al. Kadar Zat Besi Serum dan Hemoglobin Pada Anak Stunting Dan Tidak Stunting Di Kabupaten Seluma; 2019. Available from: http://ejurnal.umri.ac.id/index.php/Semnasmipakes/article/ view/1566 [Last accessed om 2021 Oct 10].

16. Hadi H. Beban Ganda Masalah Gizi dan Implikasinya Terhadap Kebijakan Pembangunan Kesehatan Nasional; 2005.

17. Milman A, Frongillo EA, de Onis M, Hwang JY. Differentia improvement among countries in child stunting is associated with long-term development and specific interventions. J Nutr. 2005;135:1415-22. https://doi.org/10.1093/jn/135.6.1415 PMid:15930446

18. Junaedi P. Kota yang sehat untuk anak. J Kesehat Perkota. 2004;11(1):45-52. 